\title{
KESALAHAN PROSES BERPIKIR MAHASISWA LAKI-LAKI DAN PEREMPUAN DALAM MEMECAHKAN MASALAH GRUP
}

\author{
Suesthi Rahayuningsih ${ }^{1}$, Feriyanto ${ }^{2}$ \\ Universitas Islam Majapahit, esthiachmad@gmail.com ${ }^{1}$ \\ Universitas Islam Majapahit, muhammad.feriyanto25@gmail.com² \\ Received : 10 September 2018, Revised : 1 Oktober 2018, Accepted : 17 Oktober 2018 \\ (C) Mathematics Education Unugiri 2018
}

\begin{abstract}
The purposes of this research are 1) to describe the errors of thinking process of male student in solving group problems; 2) to describe the errors of thinking of female student in solving group problems. This research is an explorative research using a qualitative approach. Data collection is done by task-based interviews. The errors of thinking process based on indicators: fact errors, misconceptions, operating errors and principle errors in solving group problems. The data in this study are the results of interviews and group problem tests. The results of this research show that in fact errors, male subject experienced errors in interpreting the results obtained, whereas female students do not understand the symbols $(H, \#)$ and in the context of group symbols. In conceptual errors, the second subject is the same mistake, namely the error in explaining the group and the closed nature. Likewise, with operating errors, there is no significant difference in the second subject. In principle errors, the male subject does not associate the identity element obtained in the previous step in determining the inverse, while the female subject does not associate the set $\mathrm{H}$ and binary operations.
\end{abstract}

Keywords : error thinking, problem solving, group

\begin{abstract}
Abstrak
Penelitian ini bertujuan untuk: 1) mendeskripsikan kesalahan proses berpikir mahasiswa laki-laki dalam memecahkan masalah grup; 2) mendeskripsikan kesalahan proses berpikir mahasiswa perempuan dalam memecahkan masalah grup. Penelitian ini merupakan penelitian eksploratif dengan menggunakan pendekatan kualitatif.Pengumpulan data dilakukan dengan wawancara berbasis tugas. Kesalahan proses berpikir berdasarkan indikator: kesalahan fakta, kesalahan konsep, kesalahan operasi dan kesalahan prinsip dalam memecahkan masalah grup. Data dalam penelitian ini berupa hasil wawancara dan tes masalah grup.Hasil penelitian menunjukkan bahwa pada kesalahan fakta, subjek laki-laki mengalami kesalahan menginterpretasikan hasil yang didapat, sedangkan subjek perempuan tidak memahami simbol $(H, \#)$ dan mengalami kesalahan dalam menuliskan simbol grup. Pada kesalahan konsep, kedua subjek mengalami kesalahan yang sama yaitu kesalahan dalam menjelaskan grup dan sifat tertutup. Demikian juga pada kesalahan operasi, tidak ada perbedaan yang signifikan pada kedua subjek.Pada kesalahan prinsip, subjek laki-laki tidak mengkaitkan elemen identitas yang diperoleh di langkah sebelumnya dalam menentukan invers, sedangkan subjek perempuan tidak mengkaitkan himpunan $\mathrm{H}$ dan operasi biner.
\end{abstract}

Kata kunci : kesalahan proses berpikir, pemecahan masalah, grup

1. Pendahuluan

Matematika merupakan suatu ilmu yang berhubungan atau menelaah bentuk-bentuk atau struktur-struktur yang abstrak dan hubungan-hubungan di antaranyaberupa fakta, konsep, relasi/operasi dan prinsip. Dalam memahaminya tidak cukup hanya dengan menghafal saja, hal ini sesuai dengan pendapat Soedjadi[1] bahwa objek dasar matematika yang berupa fakta, konsep, relasi/operasi, dan 
prinsip merupakan hal-hal yang abstrak sehingga untuk memahaminya tidak cukup hanya dengan menghafal tetapi dibutuhkan adanya proses berpikir.

Proses berpikir mempunyai peranan yang sangat penting dalam upaya pemecahan masalah. Sebagaimana pendapat yang dikemukakan Carson [2] "Problem solving theory and practice suggest that thinking is more important to solving problems is need".Proses berpikir adalah memanipulasi atau mengelola dan mentransformasi informasi dalam memori [3]. Ini sering dilakukan untuk membentuk konsep, bernalar dan berpikir secara kritis, membuat keputusan, berpikir kreatif dan memecahkan masalah.

Pemecahan masalah sebagai suatu usaha mencari jalan keluar dari suatu kesulitan guna mencapai suatu tujuan yang tidak begitu segera dapat dicapai [4].Dalam teori dan praktek pemecahan masalah menunjukkan bahwa berpikir sangat penting untuk pemecahan masalah daripada sekedar pengetahuan dan dimungkinkan untuk mengajarkan berpikir pada situasi dimana ada atau tidaknya pengetahuan tentang masalah yang diperlukan. Hal ini menunjukkan bahwa mengetahui proses berpikir mahasiswa dalam memecahkan suatu masalah sangat diperlukan. Dosen dapat melacak letak dan jenis kesalahan yang dilakukan mahasiswa, sehingga dosen dapat melakukan perbaikan pemahaman mahasiswa melalui pembelajaran yang dirancang sesuai dengan proses berfikir mahasiswa. Hal ini sesuai dengan Wiryoatmojo, Muhtarom \& Shodiqin [5] bahwa memecahkan masalah/soal matematika, seorang siswa pasti mengalami kesalahan proses berpikir.Kesalahan yang dimaksud yaitu: (1) Kesalahan fakta adalah kekeliruan dalam menuliskan konvensikonvensi yang dinyatakan dengan simbolsimbol matematika;(2) Kesalahan konsep adalah kekeliruan dalam menggolongkan atau mengklasifikasikan sekumpulan objek. Konsep yang dimaksud dalam matematika dapat berupa definisi;(3) Kesalahan operasi adalah kekeliruan dalam pengerjaan hitung, pengerjaan aljabar, dan pengerjaan matematika yang lain; (4) Kesalahan prinsip adalah kekeliruan dalam mengaitkan beberapa fakta atau beberapa konsep. Contoh: kesalahan dalam menggunakan rumus ataupun teorema serta kesalahan dalam menggunakan prinsipprinsip sebelumnya [1]. Subaidah [6] menyatakan bahwa kesalahan dalam menyelesaikan masalah matematika dapat dibagi menjadi tiga jenis, yaitu kesalahan konsep, kesalahan prinsip dan kesalahan operasi. Kesalahan konsep adalah kesalahan dalam menggunakan konsep-konsep yang terkait dengan materi. Kesalahan konsep dapat terjadi pada siswa di antaranya karena salah dalam memahami makna soal dan salah dalam menggunakan konsep variabel yang akan digunakan. Kesalahan prinsip adalah kesalahan yang berkaitan dengan hubungan antara dua atau lebih objek-objek matematika.Kesalahan prinsip dapat terjadi di antaranya karena salah dalam menggunakan rumus dan salah dalam menerjemahkan soal. Kesalahan operasi adalah kesalahan dalam melakukan perhitungan. Kesalahan operasi dapat terjadi karena tidak menggunakan aturan operasi atau perhitungan dengan benar.

Menurut Widodo [7], kesalahankesalahan dalam menyelesaikan masalah matematika sebagai berikut: (1) Kesalahan fakta terdiri atas (a) mahasiswa tidak mampu menyampaikan materi yang ada di soal dan (b) mahasiswa tidak mampu menyampaikan makna soal. (2) Kesalahan konsep terdiri atas (a) mahasiswa salah dalam memahami makna soal dan salah dalam menggunakan konsep variabel yang digunakan, (b) dalam menggunakan rumus, teorema, atau definisi, mahasiswa tidak menyesuaikannya dengan kondisi prasyarat berlakunya, dan (c) mahasiswa tidak menuliskan rumus, teorema atau definisi untuk menjawab permasalahan. (3) Kesalahan prinsip terdiri atas (a) mahasiswa salah dalam menerjemahkan soal dan (b) mahasiswa tidak memperhatikan prasyarat dalam menggunakan rumus, teorema, atau definisi. (4) Kesalahan operasi terdiri atas (a) mahasiswa melakukan langkah-langkah yang tidak hirarkis dalam menyelesaikan 
masalah-masalah dan (b) mahasiswa tidak mampu memanipulasi langkah-langkah untuk menjawab suatu masalah.

Suatu masalah matematika yang sama misalnya diberikan pada beberapa individu, maka akan mendapatkan respon/tanggapan yang berbeda dalam menyelesaikannya. Perbedaan cara menyelesaikan tersebut karena setiap individu memiliki keunikan dalam dirinya. Hal lain yang mungkin dapat memunculkan perbedaan setiap individu dalam merespon suatu masalah adalah adanya perbedaan laki-laki dan perempuan. Mubeen, Saeed, \& Arif [8] menjelaskan bahwa anak laki-laki berbeda dalam pencapaian prestasi matematika dari anak perempuan.Anak perempuan mencapai hasil yang lebih baik dibandingkan dengan anak laki-laki.

Perbedaan gender pada mahasiswa Program Studi Pendidikan Matematika, Fakultas Pendidikan dan Ilmu Pendidikan, Universitas Islam Majapahit signifikan. Perbandingan jumlah mahasiswa laki-laki dan perempuan pada semester 6 adalah 1:9. Hasil belajar mahasiswa selama penulis mengajar kurun waktu dua semester untuk mata kuliah struktur aljabar rendah.Rata-rata nilai kelas sebesar 55 dari skor 0-100. Hal ini menunjukkan sebagian besar mahasiswa masih mengalami kesalahan proses berpikir dalam memecahkan masalah grup. Dan juga banyak mahasiswa di perguruan tinggi yang mempunyai penguasaan konsep matematika dan aljabar yang lemah [9].Yuniati [10] juga menambahkan bahwa struktur aljabar merupakan suatu mata kuliah yang memuat konsep-konsep yang abstrak, sehingga mahasiswa seringkali mendapat kesulitan dalam mempelajarinya.Sehingga belajar struktur aljabar merupakan masalah tersendiri.Padahal aljabar abstrak, yang pada kurikulum terbaru pada Program Studi Pendidikan Matematika Universitas Islam Majapahit disebut Teori Grup merupakan mata kuliah wajib.Sebagai mata kuliah wajib, tentunya mahasiswa diharapkan dapat dapat memecahkan masalah grup yang diberikan. Sehingga penulis tertarik untuk melakukan penelitian analisis kesalahan proses berpikir mahasiswa laki-laki dan perempuan dalam memecahkan masalah grup. Artikel ini merupakan bagian dari penelitian penulis yang berjudul analisis proses berpikir mahasiswa dalam memecahkan masalah grup ditinjau dari gender. Dan tujuan penelitian ini adalah mendeskripsikan kesalahan proses berpikir mahasiswa laki-laki dalam memecahkan masalah grup dan mendeskripsikan kesalahan proses berpikir perempuan dalam memecahkan masalah grup.Indikator masing-masing jenis kesalahan adalah sebagai berikut.Adapun indikator kesalahan proses berpikir dalam penelitian ini mengadaptasi pada indikator dari Widodo [7] sebagai berikut:

1. Kesalahan fakta terdiri atas (a) mahasiswa tidak mampu menyampaikan materi yang ada di soal, (b) mahasiswa tidak mampu menyampaikan makna soal, (c) mahasiswa tidak dapat menginterpretasikan hasil yang didapatkan dan (d) Mahasiswa tidak mampu menuliskan simbol-simbol matematika.

2. Kesalahan konsep terdiri atas (a) mahasiswa salah dalam memahami makna soal dan salah dalam menggunakan konsep variabel yang digunakan, (b) mahasiswa tidak menuliskan rumus, teorema atau definisi untuk menjawab permasalahan.

3. Kesalahan operasi terdiri atas (a) mahasiswa melakukan langkah-langkah yang tidak hirarkis dalam menyelesaikan masalah-masalah dan (b) mahasiswa tidak mampu memanipulasi langkah-langkah untuk menjawab suatu masalah dan (c) mahasiswa tidak mampu melakukan perhitungan dengan menggunakan operasi matematika.

4. Kesalahan prinsip terdiri atas (a) mahasiswa salah dalam menerjemahkan soal (b) mahasiswa tidak memperhatikan prasyarat dalam menggunakan rumus, teorema, atau definisi dan (c) mahasiswa tidak dapat mengkaitkan beberapa fakta atau konsep. 


\section{Pembahasan}

Dilakukan analisis data yang diperoleh dari wawancara berbasis tugas pada subjek laki-laki (SL) dan subjek perempuan (SP) tentang kesalahan proses berpikir mahasiswa dalam memecahkan masalah grup. Berdasarkan hasil analisis data, diperoleh sebagai berikut.

Kesalahan proses berpikir mahasiswa laki-laki dalam memecahkan masalah grup sebagai berikut:

Pada jenis kesalahan fakta, subjek mengalami kesalahan proses berpikir dalam memahami arti simbol \{ \} yang ada di soal, simbol tersebut diabaikannya. Ketika diberikan $H=$ \{bilangan rasional positif\}, subjek menjelaskan $H$ adalah bilangan rasional positif. Kesalahan lain yang subjek lakukan adalah dalam menunjukkan sifat tertutup grup, subjek salah dalam menginterpretasikan hasil yang didapat yaitux \# $y=\frac{x y}{2}$ menghasilkan hasil tunggal. Subjek juga mengalami kesalahan dalam hal yang diketahui yaitu operasi biner yang diberikan dan tidak memperhatikan himpunan yang diberikan harus tak kosong dan operasi biner.Subjek tidak mampu menyampaikan makna soal dengan benar, subjek hanya melihat operasi biner yang diberikan pada masalah grup tetapi tidak memperhatikan himpunan $H$. Dan subjek tidak mampu menyebutkan materi yang ada pada soal yang diberikan pada tahap memahami masalah.

Pada jenis kesalahan konsep, subjek tidak bisa membedakan bilangan rasional positif dan himpunan bilangan rasional positif, subjek menjelaskan himpunan bilangan rasional positif itu sama dengan bilangan rasional positif. Subjek mengalami kesalahan dalam menjelaskan sifat tertutup, subjek menjelaskan sifat tertutup yaitu operasi biner \# pada $H$ bersifat tertutup jika $x \# y$ menghasilkan tunggal. Subjek juga mengalami kesalahan proses berpikir dalam menjelaskan syarat memiliki elemen identitas, subjek menjelaskan bahwa ada $e$ disebut identitas, jika $a+e=a=$ $e+e$, padahal operasi biner \# yang diberikan pada $H$. Dan juga menjelaskan definisi elemen identitas yang dimiliki grup, subjek mnjelaskan identitas adalah suatu bilangan jika dikalikan dengan elemen identitas menghasilkan bilangan itu sendiri. Subjek mengalami kesalahan dalam menjelaskan mempunyai invers, subjek menyebutkan suatu bilangan jika dikalikan inversnya sama dengan 1. Dan kesalahan berpikir juga terjadi ketika mendefinisikan bilangan rasional positif.Subjek menjelaskan bilangan rasional positif adalah bilangan yang dapat dibentuk $a / b$ dengan $a, b$ elemen bilangan bulat tanpa memberikan syarat bahwa $b \neq 0$.

Pada jenis kesalahan operasi, Sujek mengalami kesalah proses berpikir dalam menunjukan sifat tertutup grup, subjek melakukan perhitungan dengan memberi satu contoh saja yaitu 2 \# 4 yang menghasilkan 4 , dengan memberikan alasan bahwa 2 dan 4 merupakan bilangan bualat positif karena bilangan bulat positif merupakan bilangan rasional positif. Subjek mengalami kesalahan berpikir dalam melakukan perhitungan pada langkah mencari elemen identitas, subjek menggunakan operasi hitung penjumlahan yaitu $a+e=a=e+a$. Padahal operasi biner \# yang diberikan didefinisikan $x \# y=\frac{x y}{2}$, untuk setiap $x, y$ elemen $H$. Dan subjek salah dalam menentukan elemen identitas yaitu 1. Subjek juga mengalami kesalahan berpikir dalam melakukan perhitungan pada langkah mencari invers, untuk setiap $a$ elemen $H$ ada $a$ ' elemen $H$ disebut invers $a$, sehingga $a * a^{\prime}=e=a^{*} a$. Dalam menentukan invers, subjek salah memasukan nilai elemen identitas dan subjek menggunakan operasi hitung perkalian pada bilanga rasional positif, tidak mengunakan definisi operasi biner yang diberikan pada soal.

Pada jenis kesalahan prinsip, Subjek mengalami kesalahan proses berpikir dalam menunjukkan sifat assosiatif yaitu subjek menggunakan $(x \# y) \# z=x \#(y \# z)$ tanpa memperhatikan syarat untuk setiap $x, y, z$ elemen $H$. Dan dalam menerapkan aturan $e$ dikatakan elemen identitas jika $a \# e=a=e \#$ $e$ untuk setiap $a$ elemen $H$. Subjek menggunakan $a+e=a=e+e$. Subjek juga mengalami kesalahan proses berpikir dalam 
menerapkan aturan memiliki invers untuk syarat grup. Untuk setiap $a$ elemen $H$ ada unsur $a^{\prime}$ elemen $H$ disebut invers $a$ sehingga $a$ $\# a^{\prime}=e=a^{\prime} \# a$. Subjek menggunakan aa' $=1$ $=a^{\prime} a$. Pada hasil akhir penyelesaian, subjek tidak mengkaitkan himpunan $H$, hal ini terjadi karena ada kesalahan proses berpikir subjek terkait konsep grup.

Kesalahan proses berpikir mahasiswa perempuan dalam memecahkan masalah grup sebagai berikut :

Pada jenis kesalahan fakta, subjek perempuan sebagaimana subjek laki-laki mengalami kesalahan proses berpikir juga dalam memahami simbol \{ \} yang ada di soal, simbol tersebut diabaikannya. Ketika diberikan $H=$ \{bilangan rasional positif\}, subjek menjelaskan $H$ adalah bilangan rasional positif. Kesalahan lain yang subjek lakukan adalah memahami notasi operasi biner yang diberikan, subjek hanya menuliskan $x \# y=\frac{x y}{2}, \forall x, y \in H$, tanpa menuliskan mana operasi biner yang diberikan. Subjek juga salah dalam mengartikan simbol $(H, \#)$ yang pada diberikan pada soal, subjek menjelaskan bilangan rasional positif dengan operasi biner \#.Serta subjek di akhir penyelesaiannya, salah menginterpretasikan hasil yang didapatkannya. Subjek menyatakan bahwa $x \# y=\frac{x y}{2}, \forall x, y \in H$ merupakan grup, seharusnya yang merupakan grup adalah himpunan bilangan rasional positif dan diberikan operasi biner \# yang didefinisikan $x \# y=\frac{x y}{2}, \forall x, y \in H$. Seperti subjek laki-laki, subjek perempuan tidak mampu menyampaikan makna dari soal yang diberikan. Tetapi berbeda dengan subjek lakilaki, Subjek perempuan selain tidak memperhatikan himpunannya juga operasi biner yang diberikan.

Pada jenis kesalahan konsep, subjek perempuan juga tidak bisa membedakan bilangan rasional positif dan himpunan bilangan rasional positif. Subjek menjelaskan $G=$ \{bilangan rasional positif\}, sebagai bilangan rasional positif bukan himpunan bilangan rasional positif. Dan kesalahan berpikir juga terjadi ketika mendefinisikan bilangan rasional positif.Subjek menjelaskan bilangan rasional positif adalah bilangan yang terdiri dari bilangan bulat positif, bilangan nol, bilangan bulat negative dan bilangan prima.Subjek tidak bisa menjelaskan sifat tertutup yang dimiliki grup. Kesalahan proses berpikir subjek lainnya, subjek mendefinisikan elemen identitas yang dimiliki grup, subjek mengartikan elemen identitas adalah bilangan jika dikalikan identitas menghasilkan bilangan itu sendiri. Begitu pula subjek dalam mendefinisikan invers, subjek menjelaskan invers adalah kebalikan suatu bilangan.Subjek mengalami kesalahan juga dalam menjelaskan definisi grup, subjek menyebutkan grup adalah operasi yang memiliki empat syarat yaitu tertutup, assosiatif, memiliki identitas dan memiliki invers, dengan tidak memperhatikan himpunan $H$ yang diberikan harus tak kosong dan juga tidak menjelaskan operasi binernya.

Pada jenis kesalahan operasi, subjek mengalami kesalahan berpikir dalam melakukan perhitungan pada langkah mencari elemen identitas, subjek menggunakan operasi hitung perkalian yaitu $x \# y$ dikalikan 1 sehingga menghasilkan $x \# y$. Padahal operasi biner \# yang diberikan didefinisikan $x \# y=\frac{x y}{2}$, untuk setiap $x, y$ elemen $H$. Subjek juga mengalami kesalahan berpikir dalam melakukan perhitungan pada langkah mencari invers, subjek juga menggunakan operasi hitung perkalian, yaitu x.x $=1$ tidak mengunakan definisi opersi biner yang diberikan pada soal.

Pada jenis kesalahan prinsip, subjek mengalami kesalahan proses berpikir dalam menunjukkan elemen identitas, subjek menerapkan elemen identitas yang dimiliki grup seharusnya dengan $x * e=x=x * e$ untuk setiap $x$ elemen $H$. Subjek menggunakan $x * y$ dikalikan 1. Subjek juga mengalami kesalahan proses berpikir dalam menerapkan aturan memiliki invers untuk syarat grup. Untuk setiap $x$ elemen $H$ ada unsur $a$ ' elemen $H$ disebut invers $a$ sehingga $x * x^{\prime}=e=x^{\prime}{ }^{*} x$. Subjek menggunakan $x . x^{\prime}=1$, satu sisi saja dan operasi yang diberikan bukan opersi biner pada soal. Subjek mengalami kesalahan dalam 
menunjukkan $(H, \#)$ merupakan grup, subjek tidak memperhatikan himpunan $H$ yang diberikan.Subjek tidak memperhatikan prasyarat, dalam menentukan elemen identitas dan invers. Pada hasil akhir penyelesaian, subjek tidak mengkaitkan himpunan $H$ dan operasi biner yang diberikan dengan $x \# y=\frac{x y}{2}$, $\forall \in H$, hal ini karena terjadi kesalahan berpikir berpikir subjek tentang konsep grup. Serta mengalami kesalahan proses berpikir dalam nenunjukkan grup karena salah dalam menunjukkan memiliki elemen identitas dan memiliki invers.

Perbedaan kesalahan proses berpikir subjek laki-laki dan subjek perempuan dalam memecahkan masalah grup dapat dilihat pada tabel 1. Persamaan kesalahan proses berpikir subjek laki-laki dan perempuan dalam memecahkan masalah grup dapat dilihat pada tabel 2.

Subjek laki-laki lebih bisa memahami simbol-simbol pada masalah grup daripada subjek perempuan. Subjek laki-laki lebih unggul dalam mengabstraksi suatu masalah hal ini sejalan dengan Kholishoh, Pramudya\&Kurniawati [11] siswa laki-laki mempunyai daya abstraksi yang lebih tinggi daripada siswa perempuan sehingga memungkinkan siswa laki-laki lebih baik daripada siswa perempuan dalam bidang matematika, karena pada umumnya matematika berkenaan dengan pengertian yang abstrak. Dan anak laki-laki lebih unggul daripada anak perempuan dalam bidang aljabar [12].Subjek perempuan dapat mengkaitkan elemen identitas yang diperoleh untuk menentukan invers pada masalah grup daripada subjek laki-laki.Hal ini menunjukkan mahasiswa perempuan dapat menyelesaikan secara sistematis dan berurutan sesuai dengan Rahayuningsih [13] bahwa siswa perempuan lebih sistematis dalam menyelesaikan masalah yang diberikan daripada siswa laki-laki.Subjek perempuan lebih detail dalam menyebutkan hal yang diketahui di soal daripada subjek lakilaki. Hal ini sejalan dengan Macoby \&Jacklin[14] hasil penelitian mengenai gender menemukan adanya perbedaan gender yaitu perempuan lebih superior dalam komprehensif verbal, kefasihan kata, dan komunikasi.

\section{Tabel 1. Perbedaan kesalahan proses berpikir SL dan SP}

\begin{tabular}{|c|c|c|c|}
\hline No & $\begin{array}{l}\text { Jenis } \\
\text { kesalahan }\end{array}$ & SL & SP \\
\hline 1. & $\begin{array}{l}\text { Kesalahan } \\
\text { fakta }\end{array}$ & $\begin{array}{l}\text { - Dalam } \\
\text { menunjukan } \\
\text { sifat tertutup } \\
\text { subjek } \\
\text { mengalami } \\
\text { kesalahan } \\
\text { menginterpr } \\
\text { etasikan } \\
\text { hasil yang } \\
\text { didapat. }\end{array}$ & 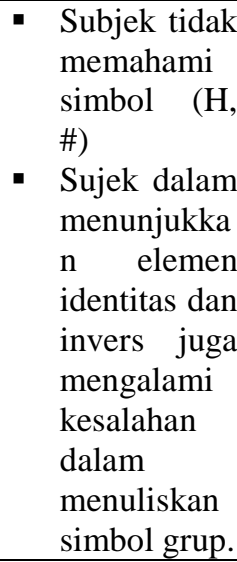 \\
\hline 2. & $\begin{array}{l}\text { Kesalahan } \\
\text { konsep }\end{array}$ & $\begin{array}{l}\text { - Subjek } \\
\text { mengalami } \\
\text { kesalahan } \\
\text { dalam } \\
\text { menjelaskan } \\
\text { sifat tertutup } \\
\text { grup. } \\
\text { - Subjek salah } \\
\text { dalam } \\
\text { menjelaskan } \\
\text { grup, grup } \\
\text { adalah } \\
\text { operasi yang } \\
\text { memenuhi } 4 \\
\text { syarat. } \\
\end{array}$ & $\begin{array}{l}\text { - } \text { Subjek tidak } \\
\text { mampu } \\
\text { menjelaskan } \\
\text { sifat tertutup } \\
\text { grup } \\
\text { - Subjek salah } \\
\text { dalam } \\
\text { menjelaskan } \\
\text { grup, grup } \\
\text { adalah yang } \\
\text { memiliki } 4 \\
\text { sifat. }\end{array}$ \\
\hline 3. & $\begin{array}{l}\text { Kesalahan } \\
\text { operasi }\end{array}$ & $\begin{array}{l}\text { - Subjek salah } \\
\text { dalam } \\
\text { menentukan } \\
\text { elemen } \\
\text { identitas } \\
\text { yaitu } 0\end{array}$ & $\begin{array}{l}\text { Subjek salah } \\
\text { dalam } \\
\text { menentukan } \\
\text { elemen } \\
\text { identitas } \\
\text { yaitu } 1\end{array}$ \\
\hline 4. & $\begin{array}{l}\text { Kesalahan } \\
\text { prinsip }\end{array}$ & $\begin{array}{l}\text { - Subjek tidak } \\
\text { mengkaitkan } \\
\text { elemen } \\
\text { identitas } \\
\text { yang } \\
\text { diperoleh di } \\
\text { langkah } \\
\text { sebelumnya } \\
\text { dalam } \\
\text { menentukan } \\
\text { invers. }\end{array}$ & $\begin{array}{l}\text { - Pada akhir } \\
\text { penyelesaia } \\
\mathrm{n}, \quad \text { subjek } \\
\text { tidak } \\
\text { mengkaitka } \\
\mathrm{n} \text { himpunan } \\
\mathrm{H} \text { dan } \\
\text { operasi } \\
\text { biner yang } \\
\text { diberikan. }\end{array}$ \\
\hline
\end{tabular}


Tabel 2. Persamaan kesalahan proses berpikir SL dan SP

\begin{tabular}{|c|c|c|}
\hline No & $\begin{array}{c}\text { Jenis } \\
\text { kesalahan }\end{array}$ & $\overline{\mathrm{SL}}$ \\
\hline 1. & $\begin{array}{l}\text { Kesalahan } \\
\text { fakta }\end{array}$ & $\begin{array}{l}\text { Subjek mengalami kesalahan } \\
\text { proses berpikir dalam memahami } \\
\text { symbol }\{\} \text { yang ada di soal, } \\
\text { simbol tersebut diabaikan. }\end{array}$ \\
\hline 2. & $\begin{array}{l}\text { Kesalahan } \\
\text { konsep }\end{array}$ & $\begin{array}{l}\text { - Subjek tidak dapat bisa } \\
\text { membedakan bilangan rasional } \\
\text { positif dan himpunan rasional } \\
\text { positif } \\
\text { - Subjek salah menjelaskan } \\
\text { elemen identitas yang dimiliki } \\
\text { grup } \\
\text { - Subjek salah dalam } \\
\text { menjelaskan invers yang } \\
\text { dimiliki grup }\end{array}$ \\
\hline 3. & $\begin{array}{l}\text { Kesalahan } \\
\text { operasi }\end{array}$ & $\begin{array}{l}\text { - Subjek mengalami kesalahan } \\
\text { berpikir dalam menentukan } \\
\text { elemenidentitas } \\
\text { - Subjek mengalami kesalahan } \\
\text { dalam menentukan invers }\end{array}$ \\
\hline 4. & $\begin{array}{l}\text { Kesalahan } \\
\text { prinsip }\end{array}$ & $\begin{array}{l}\text { - Pada hasil akhir tidak } \\
\text { mengkaitkan himpunan H yang } \\
\text { diberikan, karena terjadi } \\
\text { kesalahan proses berpikir } \\
\text { tentang konsep grup. }\end{array}$ \\
\hline
\end{tabular}

Kedua subjek mengalami kesalahan berpikir dalam memahami simbol \{\} yang ada di soal, sehingga mengakibatkan salah menyebutkan $\mathrm{H}$ sebagai bilangan rasional positif bukan himpunan bilangan rasional positif. Dan kedua subjek mengalami kesalahan proses berpikir ketika menentukan elemen identitas sehingga mengakibatkan terjadinya kesalahan dalam menentukan invers. Karena dalam menentukan eleman invers memerlukan elemen identitas.Hal ini sejalan dengan Amir [15] karena konsep matematika sangat kompleks dan cukup sulit untuk dipahami apabila konsep yang lebih sederhana belum bisa dipahami siswa.Hal ini juga terjadi ketika kedua subjek menunjukkan $\mathrm{H}$ grup yang merupakan hal yang ditanyakan di soal. Kedua subjek mengalami kesalahan proses berpikir dalam menunjukkan langkah sebelumnya yaitu syarat-syarat grup, karena kurang memahami semua arti yang ada di soal dan makna dari syarat grup. Hal itu sejalan dengan pendapat
Newman dalam Allan [16] kesalahan dalam menyelesaikan soal matematika adalah comprehension error yang mengakibatkan timbulnya kesulitan pemahaman, yaitu kesulitan berupa siswa telah mampu membaca semua kata dalam pertanyaan, tetapi tidak memahami arti keseluruhan kata-kata, sehingga siswa tidak mampu melangkah lebih lanjut sepanjang alur pemecahan masalah yang tepat.

Subjek laki-laki lebih bisa memahami simbol-simbol pada masalah grup daripada subjek perempuan. Subjek laki-laki lebih unggul dalam mengabstraksi suatu masalah hal ini sejalan dengan Kholishoh, Pramudya\&Kurniawati [11] siswa laki-laki mempunyai daya abstraksi yang lebih tinggi daripada siswa perempuan sehingga memungkinkan siswa laki-laki lebih baik daripada siswa perempuan dalam bidang matematika, karena pada umumnya matematika berkenaan dengan pengertian yang abstrak. Dan anak laki-laki lebih unggul daripada anak perempuan dalam bidang aljabar [12].Subjek perempuan dapat mengkaitkan elemen identitas yang diperoleh untuk menentukan invers pada masalah grup daripada subjek laki-laki.Hal ini menunjukkan mahasiswa perempuan dapat menyelesaikan secara sistematis dan berurutan sesuai dengan Rahayuningsih [13] bahwa siswa perempuan lebih sistematis dalam menyelesaikan masalah yang diberikan daripada siswa laki-laki.Subjek perempuan lebih detail dalam menyebutkan hal yang diketahui di soal daripada subjek lakilaki. Hal ini sejalan dengan Macoby \&Jacklin[14] hasil penelitian mengenai gender menemukan adanya perbedaan gender yaitu perempuan lebih superior dalam komprehensif verbal, kefasihan kata, dan komunikasi.

Kedua subjek mengalami kesalahan berpikir dalam memahami simbol \{\} yang ada di soal, sehingga mengakibatkan salah menyebutkan $\mathrm{H}$ sebagai bilangan rasional positif bukan himpunan bilangan rasional positif. Dan kedua subjek mengalami kesalahan proses berpikir ketika menentukan elemen identitas sehingga mengakibatkan 
terjadinya kesalahan dalam menentukan invers. Karena dalam menentukan eleman invers memerlukan elemen identitas.Hal ini sejalan dengan Amir [15] karena konsep matematika sangat kompleks dan cukup sulit untuk dipahami apabila konsep yang lebih sederhana belum bisa dipahami siswa.Hal ini juga terjadi ketika kedua subjek menunjukkan $\mathrm{H}$ grup yang merupakan hal yang ditanyakan di soal. Kedua subjek mengalami kesalahan proses berpikir dalam menunjukkan langkah sebelumnya yaitu syarat-syarat grup, karena kurang memahami semua arti yang ada di soal dan makna dari syarat grup. Hal itu sejalan dengan pendapat Newman dalam Allan [16] kesalahan dalam menyelesaikan soal matematika adalah comprehension error yang mengakibatkan timbulnya kesulitan pemahaman, yaitu kesulitan berupa siswa telah mampu membaca semua kata dalam pertanyaan, tetapi tidak memahami arti keseluruhan kata-kata, sehingga siswa tidak mampu melangkah lebih lanjut sepanjang alur pemecahan masalah yang tepat.

\section{Penutup}

Kesalahan proses berpikir subjek lakilaki, mengalami kesalahan fakta dalam menunjukkan sifat tertutup yaitu dalam menginterpretasikan hasil yang didapat. Pada kesalahan konsep, subjek mengalami kesalahan proses berpikir dalam menjelaskan sifat tertutup grup dan salah dalam menjelaskan grup, subjek mendefinisikan grup adalah operasi yang memenuhi 4 syarat. Subjek mengalami kesalahan berpikir pada kesalahan operasi yaitu subjek salah dalam menentukan elemen identitas yaitu 0.Dan pada kesalahan prinsip, subjek tidak mengkaitkan elemen identitas yang diperoleh di langkah sebelumnya dalam menentukan invers.

Kesalahan proses berpikir subjek perempuan, subjek tidak memahami symbol $(\mathrm{H}$, \#) dan dalam menunjukkan elemen identitas dan invers juga mengalami kesalahan dalam menuliskan simbol grup. Kesalahan konsep, Subjek mengalami kesalahan proses berpikir yaitu tidak mampu menjelaskan sifat tertutup grup dan salah dalam menjelaskan 74 grup, subjek mendefinisikan grup adalah yang memiliki 4 sifat. Subjek juga mengalami kesalahan proses berpikir, pada kesalahan operasi yaitu subjek salah dalam menentukan elemen identitas yaitu 1. Dan pada kesalahan prinsip, subjek mengalami kesalahan proses berpikir, pada akhir penyelesaian, subjek tidak mengkaitkan himpunan $\mathrm{H}$ dan operasi biner.

\section{Ucapan Terima Kasih}

Terima kasih. Artikel ini merupakan bagian dari hasil penelitian penulis yang berjudul Analisis Proses Berpikir Mahasiswa dalam Memecahkan Masalah Grup Ditinjau Gender yang dibiayai oleh Direktorat Riset dan Pengabdian Masyarakat (DRPM), Direktorat Jenderal Penguatan Riset dan Pengembangan Kemenristekdikti Tahun Anggaran 2018.

\section{Referensi}

[1] Soedjadi, Kiat Pendidikan Matematika di Indonesia. Jakarta: Direktorat Jendral Pendidikan Tinggi Departemen Pendidikan Nasional, (2000).

[2] Carson, J.A Problem With Problem Solving, Teaching Thinking Without Teaching Knowledge. Journal of The Mathematics Educator, 17(2),(2007) 714.

[3] Santrock, J.W. Psikologi Pendidikan. Edisi Kedua. Terjemahan: Tri Wibowo B.S. Jakarta: Kencana Prenada Media Group, (2010).

[4] Polya, G. How To Solve It. Second Edition.Princeton, New Jersey: Pricenton University Press, (1973).

[5] Wiryoatmojo,S., Muhtarom, Shodiqin,A., Kesalahan Proses Berpikir Siswa Kelas VII Sekolah Menengah Pertama (SMP) Dalam Memecahkan Masalah Matematika. Prosiding SNMPM Universitas Sebelas Maret 2013. (2013) 103-111. Maret, Solo.

[6] Subaidah. Analisis Kesalahan Siswa Kelas VII MTs N 2 Surabaya dalam Menyelesaikan Soal Terapan Persamaan Linier Satu Variabel. MATHEDU, 1(2),(2006) $171-178$.

http://journal.unugiri.ac.id/index.php?journal=JaMES 
[7] Widodo,S.A., Analisis Kesalahan Dalam Pemecahan Masalah Divergensi Tipe Membuktikan Pada Mahasiswa Matematika. Jurnal Pendidikan Matematika Undiksha.1 (1), (2013) 106114

[8] Mubeen, S., Saeed, S., \& Arif, M.H. Attitiude towards mathematics and achademic achievement in mathematics among secondary level boys and girls. IOSR Journal of Humanities and Social Sciences, 6(4),(2013) 38-41.

[9] Idris, Noraini. Enhancing Student' Undertanding in Calculus Trough Writing.International Electronic Journal of Mathematics Education,4(1),(2009) 36-55.

[10] Yuniati, Suci.Peta Konsep (Mind Mapping) Dalam Pembelajaran Struktur Aljabar.Gamatika,(3)2,(2013). https://download.portalgaruda.org/article. php? article $=297306 \& v a l=5321 \&$ title $=$ PE TA\%20KONSEP\%20(MIND\%20MAPP ING)\%20DALAM\%20PEMBELAJARA N\%20STRUKTUR\%20ALJABAR.

Diakses 30 Mei 2017

[11] Kholishoh, F.N.N., Pramudya,I., Kurniawati, I., Analisis Kesalahan Dalam Menyelesaikan Soal Cerita Dengan Fong's Schematic Model For Error Analysis Pada Materi Volume Prisma Dan Limas Ditinjau Dari Gender Siswa Kelas VIII E Smp Negeri 1 Kartasura Tahun Ajaran 2015/2016. Jurnal Pendidikan Matematika dan Matematika (JPMM) Solusi 1(1),(2017) 16-35.
[12] Dagun,Save M. Maskulin dan Feminim: Perbedaan Pria -Wanita dalam Fisiologi, Psikologi, Seksual,Karier dan Masa Depan. Jakarta: Rineka Cipta. (1991)

[13] Rahayuningsih,S.,Proses Berpikir Siswa SMA dalam Memecahkan Masalah Matematika Ditinjau dari Perbedaan Gaya Kognitif dan Perbedaan Gender. Tesis.Surabaya: PPS Universitas Negeri Surabaya (2014).

[14] Macoby, E.E. \& Jacklin, C.N.The psychology of sex differences. Stanford, CA: Stanford University Press.(1974).

[15] Amir,A. Pemahaman Konsep dan Pemecahan Masalah dalam Pembelajaran Matematika. Logaritma: Jurnal Ilmuilmu Kependidikan dan Sains, 3(1), (2015).

[16] Alan L,W. Active mathematics in classrooms : finding out why children make mistakes - and then doing something to help them. Square One: Primary Journal of the Mathematical Association of New South Wales. 15(4), (2005)http://www.curriculumsupport.edu cation.nsw.gov.au/primary/mathematics/ assets/pdf/sqone.pdf. Diakses $26 \mathrm{mei}$ 2017 
http://journal.unugiri.ac.id/index.php?journal=JaMES 